\title{
Amaryllis Lesion Nematode, Pratylenchus hippeastri Inserra et al., 2006 (Nematoda: Tylenchida: Pratylenchidae) ${ }^{1}$
}

\author{
William T. Crow ${ }^{2}$
}

\section{Introduction}

Lesion nematodes (Pratylenchus spp.) (Figure 1) are found worldwide, with different species adapted to specific habitats and host plants in different geographical regions. Common lesion nematodes reported in Florida include Pratylenchus brachyurus, Pratylenchus zeae, Pratylenchus coffeae, and Pratylenchus penetrans. While lesion nematodes have been reported parasitizing amaryllis (Hippeastrum spp.) in Florida for decades, only recently were they correctly identified as a new species, Pratylenchus hippeastri, the amaryllis lesion nematode. Since the original description, this nematode was found on other hosts in addition to amaryllis. There is evidence that populations of lesion

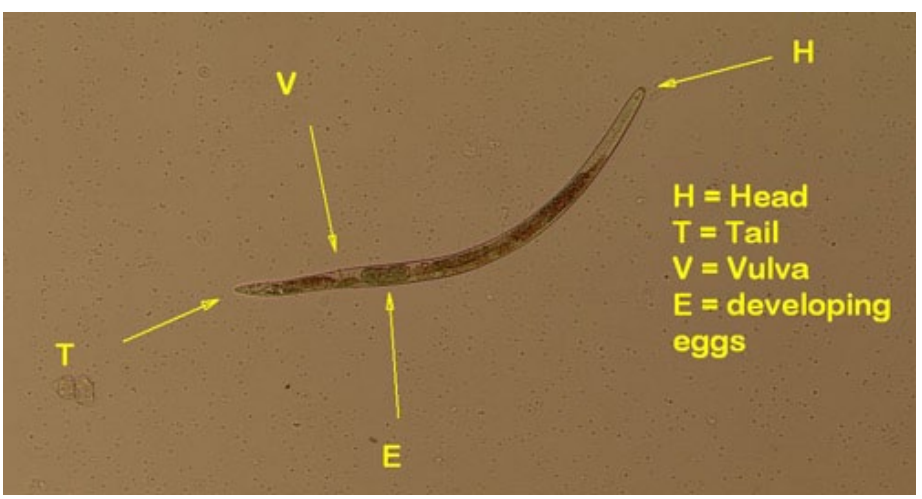

Figure 1. An amaryllis lesion nematode. The vulva is located about $78 \%$ of the nematode's body length from the anterior.

Credits: William T. Crow, University of Florida. nematodes that are morphological similar to Pratylenchus hippeastri are able to parasitize dicots in Florida. Molecular studies suggest that these populations are sibling species related to, but different from, Pratylenchus hippeastri.

\section{Distribution}

Currently, the amaryllis lesion nematode is only known in Florida, but sibling species genetically similar to Pratylenchus hippeastri occur in Russia and South Africa. These sibling species are considered members of the Pratylenchus hippeastri species complex group. It would be surprising if additional findings of amaryllis lesion nematode are not forthcoming, as propagative plant material from known hosts (amaryllis and bromeliads-see below) are widely disseminated.

\section{Life Cycle and Biology}

Lesion nematodes are migratory endoparasites, meaning that they move around within plant tissues, feeding as they go from cell to cell using their stylet. The stylet is a hollow spear-shaped structure used to puncture plant cells for entry, to inject saliva that begins digestion, and then to withdraw cell contents for ingestion (Figure 2). Reproduction is variable among species of Pratylenchus. Some species have males and females that mate, other species have only females and reproduce by parthenogenesis without

1. This document is EENY-546, one of a series of the Entomology and Nematology Department, Florida Cooperative Extension Service, Institute of Food and Agricultural Sciences, University of Florida. Original publication date January 2013. Visit the EDIS website at http://edis.ifas.ufl.edu.

2. William T. Crow, associate professor, Entomology and Nematology Department, Institute of Food and Agricultural Sciences, University of Florida, Gainesville, FL 32611. 
mating. Pratylenchus hippeastri is a male-less species that reproduces without mating. Although rare males have been found in bromeliads (but not amaryllis), they are not believed to play a role in reproduction for this species.

Lesion nematodes typically lay eggs inside of host plant tissue or in the soil nearby. Upon feeding, the nematode undergoes three more molts into a third and fourth stage juvenile, and then into an adult. At any stage (second-stage juvenile to adult), a lesion nematode may exit the host root and later enter the same or a different root. The various juvenile life stages of lesion nematodes look very similar to adults, differing only in body size and lack of a developed reproductive system. The adult female can be easily recognized by having a vulva and functional reproductive system (Figure 3); males have a bursa and spicules (Figure 4).

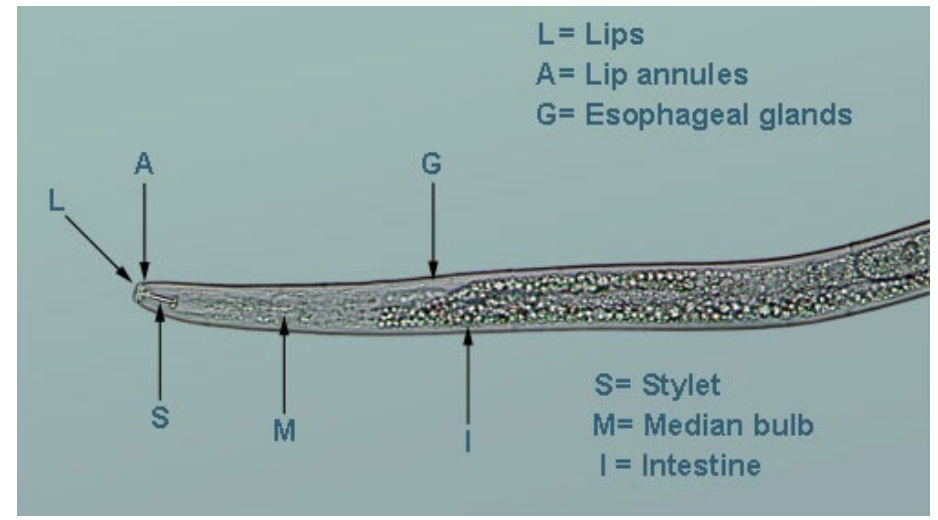

Figure 2. The head region of an amaryllis lesion nematode with flattened lips, two lip annuli, and a short, thick stylet.

Credits: William T. Crow, University of Florida.

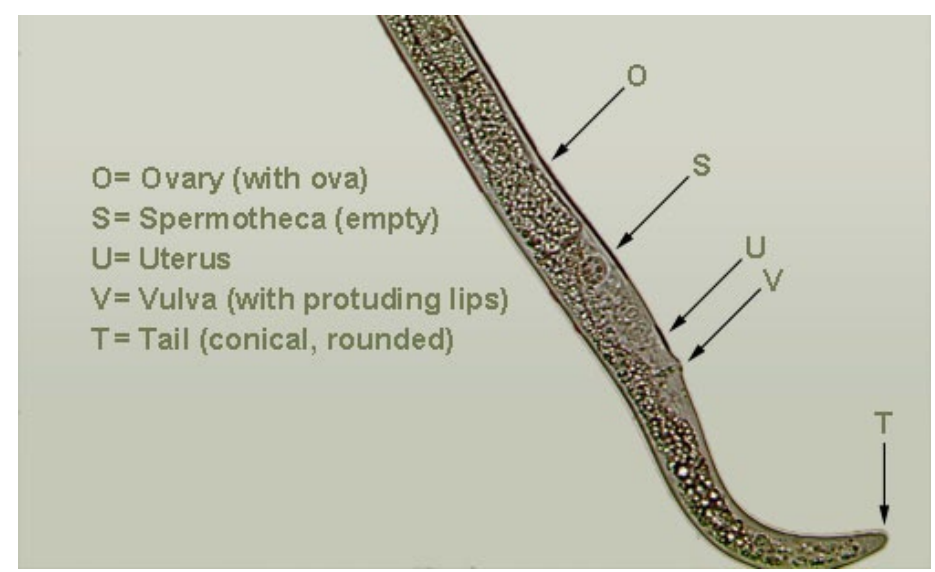

Figure 3. The tail region of a female amaryllis lesion nematode with conical, rounded tail, protruding vulval lips, and empty spermotheca. Credits: William T. Crow, University of Florida.

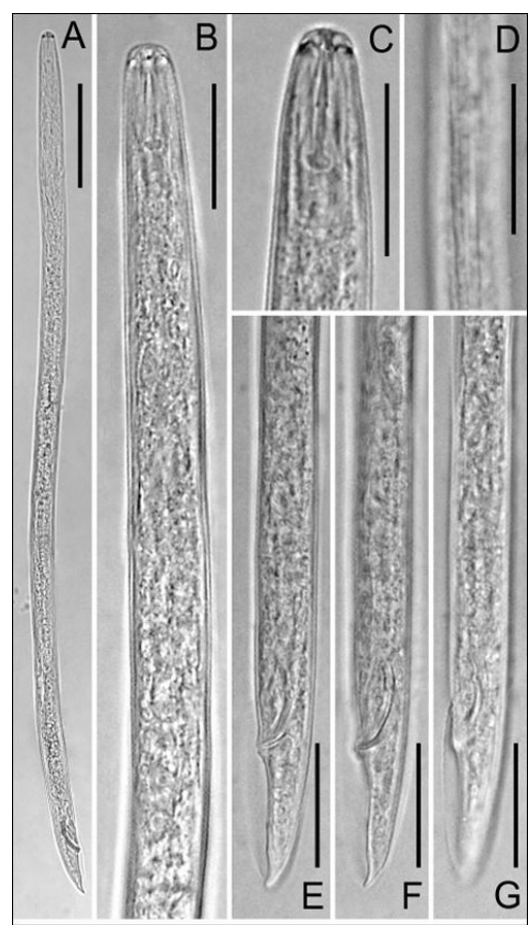

Figure 4. Light micrographs of male of Pratylenchus hippeastri. A: Entire body; B: Pharyngeal region; C: Anterior end; D: Lateral field at mid-body; E-G: Tail region at different foci. Adapted from De Luca et al., 2011.

Credits: Used with permission from CAB International.

\section{Symptoms}

Lesion nematodes are so named for the characteristic lesions (dark necrotic areas) they cause on belowground plant parts. As the nematodes tunnel through the root, the damaged cells die and collapse, forming lesions on the exterior and the interior of the root tissue (Figure 5). These lesions start out as small spots, but over time can grow until they completely girdle and effectively kill a root. On amaryllis, root lesions are reddish-brown in color (Figure 6). Root lesions caused by lesion nematodes are similar to symptoms of certain plant diseases caused by fungi. Plant roots exhibiting these symptoms should be submitted to a qualified nematode diagnostic lab such as the University of Florida Nematode Assay Lab for a positive diagnosis. 


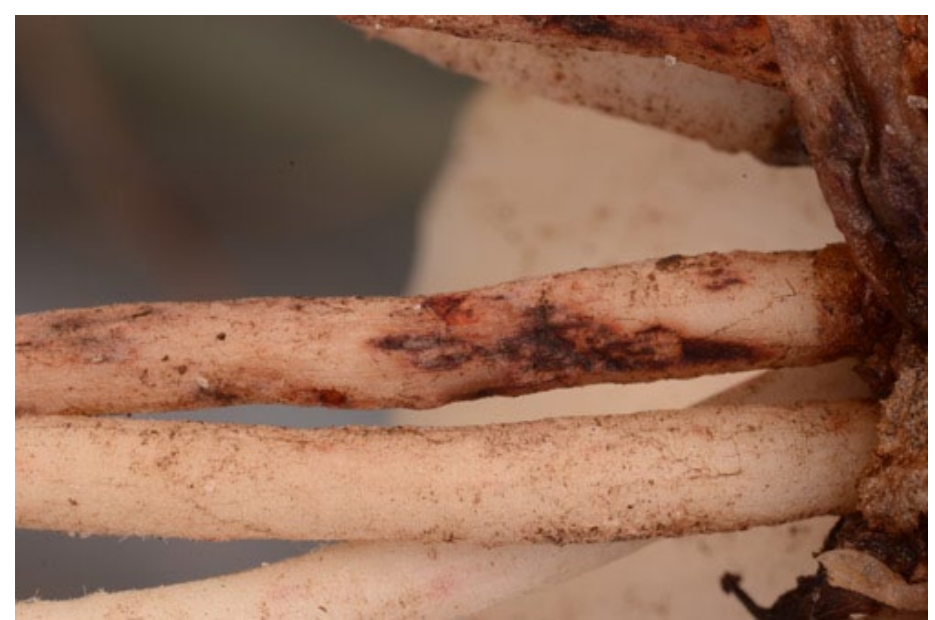

Figure 5. Root lesions caused by the amaryllis lesion nematode. Credits: William T. Crow, University of Florida.

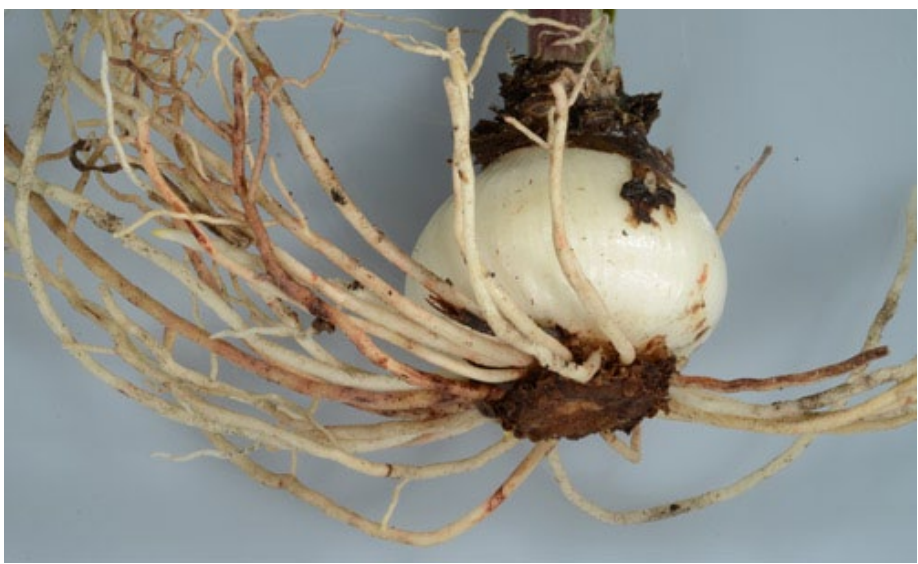

Figure 6. Amaryllis infected by lesion nematodes exhibiting characteristic reddish-brown lesions on the root system.

Credits: William T. Crow, University of Florida.

\section{Hosts}

At present the only confirmed hosts of the amaryllis lesion nematode are amaryllis and three genera of bromeliads (Guzmania, Neoregelia, and Vriesea). Nematodes belonging to the Pratylenchus hippeastri species complex have been found in Florida on other hosts such as bottle brush (Callistemon rigidus), pinto palm (Butia capitata), St. Augustinegrass (Stenotaphrum secundatum), and Zoysiagrass (Zoysia japonicum).

\section{Identification}

Lesion nematodes are characterized by having a short, thick stylet and flattened lip region (Figure 2). Female lesion nematodes have a vulva located in the posterior third of their body, and they have a single ovary. The rarity of males can separate Pratylenchus hippeastri from species that have abundant males. Several distinguishing features visible with light microscopy of live specimens can be used to separate
Pratylenchus hippeastri from certain other lesions nematodes. The vulva of Pratylenchus hippeastri is located around $78 \%$ of the nematodes body length from the anterior (Figure 1) and has slightly raised vulval lips (Figure 3 ). The tail is conical and bluntly rounded (Figure 3 ). The lip region has two annuli (Figure 2). Scanning electron microscopy of the frontal-view of Pratylenchus hippeastri reveals a smooth, undivided face with the oral disc fully fused with the labial sections. The latter is the primary distinguishing feature between Pratylenchus hippeastri and Pratylenchus scribneri, with which Pratylenchus hippeastri was misdiagnosed for half a century (Figure 7). The body length of Pratylenchus hippeastri is around 550 to $625 \mu \mathrm{m}$ and the stylet length is $15.5 \mu \mathrm{m}$.

\section{Economic Importance}

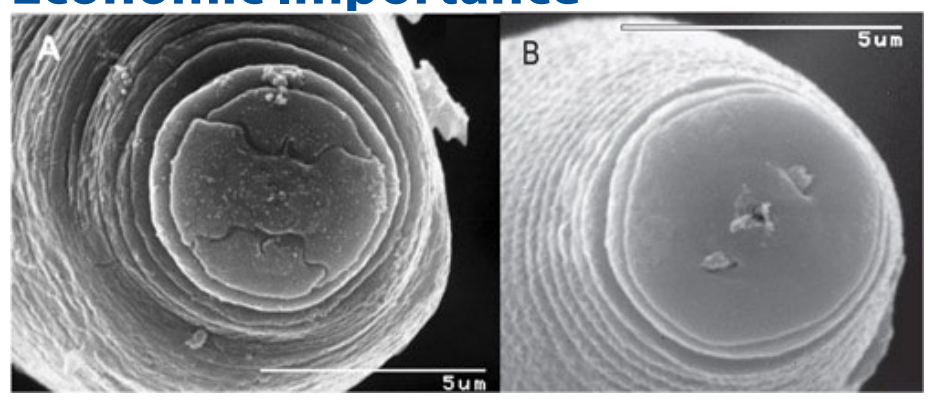

Figure 7. Scanning electron microscopy of the nematode frontalview is required to separate Pratylenchus hippeastri from Pratylenchus scribneri. A: The oral disc of Pratylenchus scribneri is divided. B: the oral disc of Pratylenchus hippeastri is fully fused. Adapted from Inserra et al., 2007 and De Luca et al., 2010.

Credits: Used with permission from CAB International.

Amaryllis lesion nematode is an important nematode pest of amaryllis in Florida. It reduces plant vigor, flower yield, and bulb size. The amount of damage caused by this nematode to other hosts such as bromeliads is currently unknown.

\section{Management}

Because Pratylenchus hippeastri is an endoparasite and amaryllis is typically propagated from bulbs, using clean bulbs is critical to avoid spread of this nematode. Removing the roots and submersing the bulbs in hot water $\left(122^{\circ} \mathrm{F}\right)$ for 20 minutes should eradicate most, if not all, nematodes present. Once an amaryllis planting is infested with lesion nematodes, only systemic nematicides will be effective against Pratylenchus hippeastri. Currently, there are no systemic nematicides labeled for this purpose. See Nematode Management for Nursery Crops or Nematode Management for Perennial Landscape Plants for current management recommendations. 


\section{Selected References}

- Christie JR, Birchfield W. 1958. Scribner's lesion nematode, a destructive parasite of amaryllis. Plant Disease Reporter 42:873-875.

- Davis EL, MacGuidwin AE. 2000. Lesion nematode disease. Plant Health Instructor DOI: 10.1094/

PHI-2000-1030-02.

- De Luca F, Troccoli A, Duncan LW, Subbotin SA, Waeyenberge L, Moens M, Inserra RN. 2010. Characterisation of a population of Pratylenchus hippeastri from bromeliads and description of two related new species, $P$. floridensis $\mathrm{n}$. sp. and P. parafloridensis $\mathrm{n}$. sp. from grasses in Florida. Nematology 12: 847-868.

- Inserra RN, Trocoli A, Gozel U, Bernard EC, Dunn D, Duncan LW. 2007. Pratylenchus hippeastri n. sp. (Nematoda: Pratylenchidae) from amaryllis in Florida with notes on $P$. scribneri and $P$. hexincisus. Nematology 9: $25-42$. 